\begin{tabular}{|l|l|l||}
\hline \multicolumn{2}{|c|}{ PublisherInfo } \\
\hline \hline PublisherName & $:$ & BioMed Central \\
\hline \hline PublisherLocation & $:$ & London \\
\hline \hline PublisherImprintName & $:$ & BioMed Central \\
\hline \hline
\end{tabular}

\title{
The North American Rheumatoid Arthritis Consortium
}

\begin{tabular}{|l|l|l||}
\hline \multicolumn{2}{|c|}{ ArticleInfo } \\
\hline \hline ArticleID & $:$ & 22 \\
\hline \hline ArticleDOI & $:$ & 10.1186 /ar-2000-2-webreport0012 \\
\hline \hline ArticleCitationID & $:$ & 0012 \\
\hline \hline ArticleSequenceNumber & $:$ & 18 \\
\hline \hline ArticleCategory & $:$ & Web Report \\
\hline ArticleFirstPage & $:$ & 1 \\
\hline \hline ArticleLastPage & $:$ & 2 \\
\hline \hline & & RegistrationDate : 2000-5-10 \\
\hline ArticleHistory & $:$ & OnlineDate \\
\hline \hline ArticleCopyright & $:$ & Current Science Ltd2000-10 \\
\hline \hline ArticleGrants & $:$ & \\
\hline \hline ArticleContext & $:$ & 130752211 \\
\hline \hline
\end{tabular}




\section{Overview}

The North American Rheumatoid Arthritis Consortium (NARAC) is a group of ten research sites located across the United States, cooperating to conduct research on the genetics of rheumatoid arthritis. The initial goal is to identify 1000 families in which two or more siblings are affected with rheumatoid arthritis. Detailed clinical information, hand radiographs, serum, and peripheral blood DNA will be obtained from each affected sibling. This database and serum and DNA repository, which is sponsored by the National Institutes of Health and the Arthritis Foundation, will form a resource for the entire scientific community to allow for a comprehensive analysis of genetic susceptibility to rheumatoid arthritis. Criteria for enrollment include the following: 1) two or more siblings with rheumatoid arthritis by American College of Rheumatology criteria, 2) at least one sibling with documented erosions on hand radiographs and 3) one of the two siblings with onset of disease between the ages of 18 and 60 .

\section{References}

1. The North American Rheumatoid Arthritis Consortium. [http://medicine.ucsf.edu/divisions/rheum/ narac/]

This PDF file was created after publication. 